que pressupóem um crescimento ilimitado, que tiveram em Prestes Maia um representante. Assinala-se o conflito entre o padrão urbanístico dos bairros-jardins e os modelos de vias retilíneas e largas consagrados nos códigos das primeiras décadas do século $\mathrm{XX}$, além dos embates entre defensores e críticos da verticalização do centro da cidade, e entre propostas de criação de grandes avenidas por meio do alargamento de vias existentes ou criação de novas vias em fundos de vale.

Ao assinalar o descompasso entre planos e intervençôes, o autor contrapóe ao teor e a amplitude dos projetos as características e o caráter parcial das realizações. Mostra o limite geográfico restrito atingido pelas reformas urbanas do início do século XX. Citando instrumentos como as taxas de calçamento e a contribuição de melhoria, indica a dificuldade encontrada de pôr em prática medidas amplamente defensáveis em termos conceituais. Referindo-se aos casos dos urbanistas Anhaia Melo e Prestes Maia, mostra os limites da aplicação de muitas das ditas "soluções racionais" recomendadas por urbanistas, que não conseguiram efetuálas mesmo quando prefeitos da cidade. Tal descompasso evidencia não apenas limitações orçamentárias, como também a busca em conciliar a ação pública com interesses locais. Ao analisar a trajetória entre a formulação das propostas urbanas e a eventual intervenção, Campos evidencia os ajustes introduzidos e as negociações efetivadas que buscavam conciliar interesses diversos de setores do capital, de valorização fundiária, de reprodução da força de trabalho e de legitimação dos dirigentes. Analisando este percurso entre proposiçōes e açôes, o autor salienta como "o processo de intervenção urbanística, longe de ser mero campo de progresso técnico, implicava opções com sérias conseqüências sobre as condições de vida, acumulação e produção vigentes no centro urbano" (Campos, 2002, p.283).

Em meio a tais embates, o autor assinala o delineamento de algumas tendências, entre as quais a mais nítida é a crescente ênfase das intervenções - em especial a partir da década de 1920 - nas questóes referentes a tráfego e sistema viário. Tal ênfase ocorre em detrimento de outras demandas - estéticas, habitacionais e de lazer - e se direciona, sobretudo, ao estímulo do transporte particular e do ônibus entre as modalidades de transporte coletivo. O Plano de Avenidas - concebido por Prestes Maia no final da década de 1920 surge como um momento exemplar desta tendência.
Ao final de sua análise, Campos salienta o poder de permanência da visão expansionista e "rodoviarista" de Ulhoa Cintra e de Prestes Maia, enumerando intervençôes recentes na cidade de São Paulo que concretizam diretrizes do Plano de Avenidas, como a passagem subterrânea da avenida Tiradentes, que integra o perímetro de irradiação e túneis e vias ligando as avenidas Bandeirantes e Salim Maluf, que integram o terceiro circuito perimetral.

Ao tratar a cidade de São Paulo como um campo de disputas entre idéias, práticas e projetos urbanísticos, que contrapõem concepções que afetam interesses diversos, o livro desvenda o papel central de urbanistas que atuaram no período em análise na mediação de conflitos de interesses e de visões de cidade. Analisando esta atuação, mostra como o domínio de técnicas, o conhecimento de experiências internacionais e uma suposta neutralidade fundamentada numa pretensa racionalidade foram instrumentos importantes. Mas, o grande mérito da obra é precisamente sublinhar o vasto campo de lutas - tantas vezes escamoteado em abordagens restritas a aspectos formais - que permeia o pensamento e a prática do urbanismo.

\section{CIDADES ESTREITAMENTE VIGIADAS: O DETETIVE E O URBANISTA}

Robert Moses Pechman

Apresentação de Stella Bresciani

Rio de Janeiro: Casa da Palavra, 2002.

Amilcar Torrão Filho

Clarice Lispector escreveu em uma crônica que, quando criança, acreditava que os livros nasciam em árvores. Hoje sabemos que eles têm autores e são resultado de muito trabalho e de um esforço de imaginação. Há ainda aqueles que são escritos inspirados em outros livros, que lhes abrem o caminho ou servem como fonte de informação, estímulo ou inspiração. É este o caso de Cidades estreitamente vigiadas: o detetive e o urbanista, de Robert Moses Pechman, inspirado que foi pela leitura de um pequeno livro já tornado um clássico. Considera-se o autor uma destas pessoas a quem, por defeito de fabricação, os "livros desequilibram, produzem abismos, causam estragos, torcem a vontade, 
bagunçam a vida, desnorteiam o norte, enfim, mudam o rumo da vida" (Pechman, 2002, p.13). Desnorteado, bagunçado, desequilibrado, nosso autor se dedicou a estudar a cidade.

Este livro trata da paixão por livros; da paixão pelo estudo das cidades e do urbanismo; da paixão por uma cidade, que todos os brasileiros aprendemos a amar: o Rio de Janeiro. Trata-se de entender o processo de constituição de uma nova ordem social, urbana, civilizada, cortesã, "estimuladora da boa moral e da doçura dos costumes" com a chegada da família real portuguesa, na transferência inédita de uma corte européia para os tristes trópicos. O livro do professor Pechman vem preencher uma lacuna nos estudos urbanos brasileiros ao destacar um período tão importante da história do Rio de Janeiro, e de todo o País, que até então só vinha atraindo a atenção da historiografia política ou social. Apesar da ruptura tão grande que significou para a Cidade Maravilhosa a chegada da corte, os melhoramentos urbanos de D. João não suscitaram um interesse muito além do anedótico para a historiografia do período.

Civilização e barbárie se enfrentam no Rio que se "civiliza”. Um conceito não vive sem o outro, cruciais, segundo o autor, como elementos "no processo de formulação de imagens que deu legitimidade à moderna ordem urbana brasileira, e que se fundou no que talvez pudéssemos chamar de pacto urbano" (p.24). Apesar de predominantemente agrário, é na cidade, no espaço urbano, que se constitui uma pax villae, um "processo civilizatório" brasileiro, que ao mesmo tempo se opóe e se adapta à antiga ordem senhorial. É na nova capital do Reino de Portugal, e depois do Império do Brasil, que se constituirá este pacto urbano, em que o príncipe regente acomodaria, "com todos os rapapés e politesses ainda que um tanto gastos, uma sociedade cortesâ" (p.67).

Robert Pechman faz uma leitura original de suas fontes e do período que estuda. Ele, por exemplo, retoma o sentido coevo da palavra polícia: não apenas "conter a criminalidade", policiar significava também "polir, assear, adornar". Disciplinar e reprimir sim, mas tendo em vista um código de costumes e de convivência urbana, de cortesia, de chamar à ordem os que dela se desviavam, "numa espécie de 'integração social' pela civilidade" (p.72). Tão logo chega ao Rio, D. João empossa o intendente geral da polícia, encarregado de levar a cabo a "reforma urbana" empreendida na renovada capital: zelar pelo cuidado e conservação da cidade, de seus logradouros públicos, pelo cumprimento da Lei e repressão ao crime e pela obediência ao código de moral e costumes da urbanidade que se pretende implantar. A polícia é, também, um poderoso agente de civilização; e a cidade é o laboratório onde se experimenta o "modelo nacional de ordem e civilização", é "o lugar da exemplaridade" (p.107).

Por meio do delicioso romance de Manuel Antonio de Almeida, Memórias de um sargento de milícias, Robert Pechman observa as estratégias de controle da nova policia urbana e as brechas de resistência encontradas por parte da população que não se enquadrava nas "novas práticas da sociabilidade nos marcos do que se passou a chamar de civilidade" (p.76). Por meio da persuasão a Intendência Geral de Polícia procura incorporar o indivíduo ao mundo da ordem, reconhecer a esfera pública, tão difícil numa sociedade como a brasileira, na qual a esfera privada sempre ocupou espaço tão importante. Observa o autor que, ao contrário da tradição colonial, de exílio, degredo, morte natural e, no limite, condenação à morte, a nova ordem de civilidade se fundamenta, precisamente, "a partir do 'reconhecimento' e 'incorporação' da nova camada de indivíduos moradores da cidade, os quais têm que ser trazidos para a órbita da sociabilidade" (p.80). Função que caberá à polícia, aos novos manuais de civilidade que se multiplicam na recém-liberada imprensa, pregando a doçura dos costumes e o respeito às hierarquias e à ordem estabelecida, à civilidade entendida como "antídoto à revolta, à maldade e ao ócio" (p.88). Estamos aqui, como lembra o autor, no domínio da política: "Ordem, etiqueta, cortesia, civilidade, política acabam se articulando na manutenção da paz social e devem ser entendidas como fazendo parte de um mesmo processo de construção de imagens sobre o que se deva ser o convívio social" (p.90). Mas o efeito da polícia na garantia da estabilidade social, da pax urbana, não é maior do que o potencial sedutor da cidade, "sua capacidade de evocar a civilização, seu poder de atrair para um projeto que prometia o futuro" (p.112), que prometia a ordem, a civilização e o controle dos bárbaros que assaltavam incessantemente os muros da civilidade.

A cidade colonial, vista como defasada, inculta, desorganizada, não serve aos propósitos do processo 
civilizador, não está preparada para receber o "espírito cortesão" e as novas formas de sociabilidade que chegam com a família real portuguesa e, em seguida, com o Império. Uma nova cidade deve-se desenvolver para abrigar esta sociabilidade cortesã que se forma, já que, lembra o autor, corte e cidade, "apesar de ocuparem o mesmo espaço, não são a mesma coisa” (p.238). Antes mesmo de ser cidade, o Rio de Janeiro se tornou corte, espaço onde se gesta a civilidade, onde a burguesia se "aristocratiza", onde a civilização luta contra a barbárie. Daí a necessidade de um romance urbano que sintetize as definiçóes da cidade, da corte e da civilidade; mas, para que nasça este romance urbano, "é preciso, antes de tudo, inventar o urbano, ainda que a cidade exista já há muito tempo". O urbano entendido como a "invenção social na cidade" (p.204), como o conjunto de normas, regras e modelos que marcam as fronteiras entre civilização e barbárie.

$\mathrm{Na}$ construção desta sociabilidade urbana, Pechman destaca o terror que os habitantes da cidade brasileira do Império sentiam em relação aos escravos. Mas sua originalidade está em perceber neste medo não somente o desejo de manter a ordem senhorial escravista, mas acima de tudo de evitar a desordem urbana. Pois na cidade "o sistema escravista não pode ser pensado fora de um projeto de ordem urbana” (p.304). A particularidade da escravidão urbana, marcada pela "ausência do feitor", faz do escravo "não necessariamente um revoltoso mas, certamente um desordeiro. No ambiente urbano, o escravo não é só um cativo, ele é, também - à sua maneira - um 'habitante' da cidade" (p.304). Assim, no Rio de Janeiro da corte não é apenas o medo de que a cidade se transforme num Haiti que aterroriza os brancos e preocupa a polícia, mas de que ela se torne mais parecida a Londres ou Paris, com suas hordas de miseráveis e desocupados e seu terrível "espetáculo da pobreza”. O medo ao negro, como diz o autor, "se urbaniza e, ao se urbanizar, faz do negro a imagem da anticidade daquilo que não deve ser a cidade" (p.310).

O escravo pode não apenas "incendiar" a cidade mas acima de tudo contaminá-la, tanto física quanto moralmente. É assim que ele aparece na literatura, no teatro, nos folhetins, nas teses de medicina. Como nesta de 1846, citada por Pechman, na qual o doutor Manoel Moraes e Valle afirma ser o "Rio de Janeiro, cidade vasta e populosa (...) onde o polido do cortesão se acha mesclado à grosseira familiaridade africana, onde o encontro dos costumes americanos, africanos e europeus que se chocam e se repelem, constitui um todo informe" (p.314). Uma proximidade que ameaça a cidade e sua ética cortês e urbana.

A cidade é, assim, o espaço desejado e temido, céu e inferno da civilização, cheia de mistérios, tentações e perigos insondáveis, que atrai talentos como o de Juliano Sorel de Stendhal, de Luciano de Rubempré e de Eugênio de Rastignac de Balzac para, em seguida, destruí-los. Cidade que atrai também os "rejeitados da civilização", onde se acomodam "os dissolutos, os preguiçosos, os mendigos, os turbulentos e os esbanjadores de dinheiro. ${ }^{1} \mathrm{~A}$ cidade dos vícios e crimes subterrâneos, que irrompem quando menos se espera, dos selvagens, das classes perigosas, dos que se ocultam para contaminar a civilização. Daí a necessidade do detetive para descortinar o mal que se acastela nas fímbrias do urbano. O romance policial é o caminho através do qual Pechman vai se "defrontar com as questōes da ordem urbana, tão caras na configuração da urbanidade quanto do próprio urbanismo" (p.272). Se a cidade é o "campo de batalha onde a vida social vai ser jogada e, de sua conquista, depende a sobrevivência da ordem social (p.275)", o romance policial nasce para detectar o mal escondido; e o detetive nasce com a incumbência de solver os seus mistérios e identificar seus criminosos e os bárbaros que ameaçam o "pacto urbano" (p.290). E aí vem o golpe de mestre do autor - para usar uma linguagem próxima do romance policial: identificar o detetive ao urbanista. $\mathrm{O}$ detetive, treinado no espírito racionalista-científico derivado da Ilustração, "está na origem de um esforço de leitura da cidade que irá desembocar, no século XX, no urbanista, cuja missão é transformar a cidade num objeto de todo transparente com o fito de desvendar seus enigmas e, ao fazê-lo, enquadrar a cidade de forma a controlar toda ameaça de desordem e quebra da lei” (p.282). Dessa maneira entende Pechman o aparecimento dos engenheiros-urbanistas e as grandes reformas urbanas pelas quais passa o Rio de Janeiro no século XX, então capital republicana.

Os urbanistas têm como função a defesa da cidade contra os bárbaros que a querem desfigurar, macular

1 Maria Stella Martins Bresciani, Londres e Paris no século XIX: o espetáculo da pobreza [1982]. 5.ed. São Paulo: Brasiliense, 1989, p.42. (Col. Tudo é História, v. 52.) 
sua beleza, em geral os pobres. Dar uma ordenação racional e científica à organização urbana. Realizar a antítese daquilo pelo qual se critica as cidades medieval e colonial, que crescem desordenada, orgânica e livremente, de acordo com a vontade e os "caprichos" de seus moradores, muitas vezes estes bárbaros a que tanto se teme. Este urbanismo que cria a cidade sem criar o cidadão.

Robert Pechman utiliza de maneira criativa uma grande diversidade de fontes: crônicas, folhetins, romances, peças teatrais, revistas de ano, teses de medicina, correspondência e documentação dos órgãos de polícia, manuais de civilidade, tudo isso numa prosa fluente, acessível, às vezes agradavelmente informal (os tradicionais agradecimentos são substituídos, por exemplo, por um carioquíssimo Aquele Abraço), mas sem perder o rigor e a sofisticação da análise. Isso sem contar referências culturais variadas, como a poesia contemporânea, o cinema tcheco, do qual empresta o título de seu livro (do célebre filme Trens estreitamente vigiados, de Jiri Menzel), ao romance policial (cujos seguidores constituem uma seita fiel e que encontrarão nesta obra uma leitura muito prazerosa), além de um projeto gráfico excelente.

Para terminar vale lembrar que o livro que mudou o rumo de sua vida e inspirou suas pesquisas em urbanismo foi Londres e Paris no século XIX: o espetáculo da pobreza, de Maria Stella Martins Bresciani, orientadora deste trabalho apresentado como doutorado na Unicamp, que certamente inspirou a muitos outros estudiosos da cidade no Brasil.

\section{ESTÉTICA DA GINGA - A ARQUITETURA DAS FAVELAS ATRAVÉS DA OBRA DE HÉLIO OITICICA}

Paola Berenstein Jacques

Rio de Janeiro: Editora Casa da Palavra, Rio Arte, 2002.

Pasqualino Romano Magnavita

No mundo editorial contemporâneo a publicação de livros relacionados com aspectos teóricos/conceituais inovadores, visando estabelecer parâmetros inéditos na formação discursiva da arquitetura e de seus fundamentos, tem se demostrado um aconteci- mento cada vez mais raro. Paradoxalmente, hoje, como nunca, a publicaçáo de livros e textos sobre arquitetura tem crescido exponencialmente. Evidentemente, a questão não se encontra na proliferação viral de publicações que preenchem as estantes de livrarias e bibliotecas especializadas, mas no uso de novas formas de pensar, no emprego de novas lógicas, de instrumental teórico inovador. Regra geral, a quase totalidade de livros e textos que integram o universo editoral contemporâneo relacionados com a arquitetura constitui um incomensurável catálogo de repetições e reciclagens conceituais herdado da modernidade.

O livro Estética da ginga de Paola Berenstein Jacques constitui um singular acontecimento no âmbito da cultura arquitetônica em nosso país. Filosoficamente, o termo Acontecimento, no sentido empregado por Deleuze/Guattari, ocorre quando surge um problema, um questionamento que favorece uma virtualização. Esse processo imaginativo que constitui o Virtual pressupõe o Atual e visa a sua atualização. Quando o virtual, como entidade, adquire consistência, tal fato constitui um acontecimento, um ato de criação. Propriamente, o acontecimento, como processo, não começa nem acaba, pois tem uma parte sombria e secreta que não pára de se subtrair ou de se acrescentar à sua atualização. É um real sem ser atual, ideal sem ser abstrato. $\mathrm{O}$ acontecimento, em sua potencialidade, é pura reserva. A Estética da ginga, como acontecimento, possui justamente essa potencialidade criativa. Trata-se de um ensaio teórico/conceitual aberto que procura sua atualização vislumbrando uma nova forma de pensar os fundamentos da arquitetura e, dessa forma, tem como alvo contrapor-se às formas convencionais e acadêmicas de entender a arquitetura.

A mudança nas formas de pensar constitui um referencial marcante da cultura contemporânea. Tal fato é bastante evidente quando se tem presente o processo de deconstrução da lógica binária e do modelo arborescente que the corresponde, herança da condição cultural moderna. Entre as formas de pensar contemporâneas, o surgimento da lógica da multiplicidade e a percepção rizomática que lhe corresponde (Deleuze \& Guattari) constituem um marco significativo dessa deconstrução na forma de pensar. Inserindo-se nesse processo deconstrutivista, a autora optou por adotar como ferramenta teórica o repertório conceitual contido na referencial obra Mil platôs escrito em parceria 